\title{
Students' Soft Skills as a Factor of their Professional Competitiveness Improvement
}

\author{
Aleksey Y. Lozovoy ${ }^{1}$, Elena K. Zashchitina ${ }^{2}$, Irina A. Nazvanova ${ }^{3}$ \\ Southern Federal University \\ Rostov-on-Don, Russia \\ ${ }^{1}$ lozovoy@sfedu.ru, ${ }^{2}$ ekzashitina@ @ffedu.ru, ${ }^{3}$ nazvanova@sfedu.ru
}

\begin{abstract}
This paper discusses the issues regarding the soft skills needful for a future career. Therefore, a deep analysis of the best soft skills training practices both Russian and foreign was made. The paper shows scientific and innovative methods and mechanisms developed for the improvement of soft skills within the framework of modern educational technologies.
\end{abstract}

Key words-soft skills; occupations of the future; competitiveness; labor market

\section{INTRODUCTION}

Digital revolution, tangible in every developing segment of modern society, has led to the emergence of a new type of economy - knowledge-based economy. The results of the new type economy have comprised by now a significant part of the national GNP of BRICS countries. Thereby, in recent decades, the labor market has undergone permanent changes regarding the nomenclature and content of qualification requirements for potential employees, the paradigm of professional competencies and general cultural knowledge of both industry specialists and future graduates. Acceleration of technological development leads to the fact that students of universities and colleges are often lagging behind in respect of getting the necessary qualifications. The way people make global and situational decisions in the personal and professional spheres as well as the manner how universities create programs and how organizations hire and train employees is changing. The central place in this ever-changing socio-economic picture of the modern world is occupied by updated knowledge; they are the basis and driver of the development of the social and economic life of individuals and entire countries.

The consequence of technological, sectoral and economic transformations is that lifelong learning, as a means of providing employment opportunities, as well as professional and career growth, has replaced education for life.

The development of the knowledge-based economy created new incentives for people to acquire certain skills through education, due to the fact that there is an established correlation between the level of education and the position of the employee in the labor market, which demonstrates that a higher level of education helps to avoid unemployment and to hold the job in case of recession. So, Figure 1 shows the relationship between the level of education and the level of employment of people aged from 25 to 64 in respect of a country and a partner of the Organization for Economic Cooperation and Development [1]
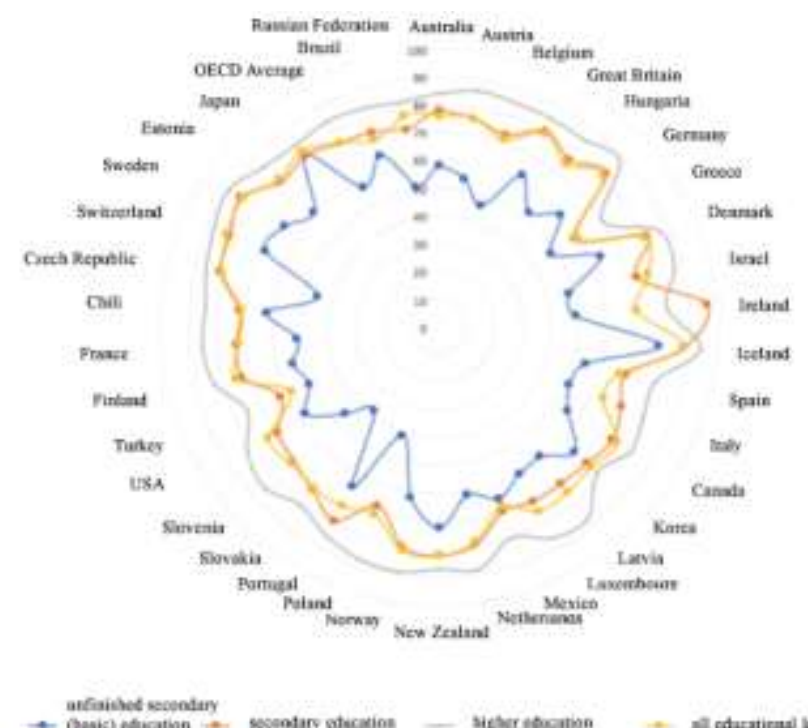

Fig. 1. Occupational level of OECD countries of the age range of 25-64 in terms of education (2016), \%

So, we can conclude that the highest percentage of employment is reached by people with higher education (with the exception of Ireland, where employees with secondary education prevail).

However, high personal and professional competitiveness cannot be guaranteed only by professional development of a person and updating of special, so-called hard skills. The latter should be understood as (hard) academic skills acquired by a specialist, which mean an expert level of special professional competencies, knowledge of the methods and procedures necessary for the successful performance of official duties.

One of the many consequences of the processes of digitalization and globalization of the world has become supertechnologization, structural integrity and complexity of the tasks to be solved, which in turn required the involvement of not individual specialists, but groups of professionals from different areas of knowledge and working on the problem not always in one the same room, enterprise, city and country. Appeared a necessity to work in team, and as a result, to 
communicate, recognize and understand emotions, make decisions and implement them, control time and labor.

Thus, the competitiveness of a specialist is determined not only by professional competencies and the "hard" skills underlying them, but by "soft" skills as well.

In recent years, the phenomenon of "soft skills" has been the focus of attention of many scientific disciplines: pedagogy, psychology, sociology, management theory.

In the most generalized form, "soft" skills are, firstly, a set of certain personal qualities: responsibility, discipline, selfmanagement and, secondly, managerial skills: communication, in particular, the ability to listen and to hear; teamwork, emotional intelligence, time management, conscious leadership, problem solving skills, critical thinking skills. [2]

\section{MATERIALS AND METHODS}

The analysis of Federal State Educational Standards shows that to a certain extent the substantial part of "soft skills" coincides with the content of general cultural (GCC) and general professional (GPC) competencies of existing educational standards for bachelor and Master programs. Nevertheless, the presence of such competencies among the requirements for the development of academic disciplines cannot always guarantee the development of students' soft skills at a sufficient level. On the one hand, this can be explained by their relevance to general cultural, or rather, by their irrelevance to professional competencies. But it is precisely the development of professional competencies - hard skills are the skills teachers and students make their efforts to, they are in the center of attention, control of measurement and evaluation. On the other hand, the nature of soft and hard skills speaks of their close relationship and interdependence. In recent years, in world leading universities, vocational education has focused on the development of soft and skills in their unity [3]. In (Table 1), an approximate list of competencies and the number of disciplines forming soft skills is presented on the example of master's programs in the subject area of 38.04.02 Management that are implemented at the Southern Federal University (SFedU).

TABLE I. THE LIST OF COMPETENCIES AND THE NUMBER OF DEVELOPING SOFT SKILLS COURSES PRESENTED IN AN EDUCATIONAL PROGRAM OF HIGHER EDUCATION IN THE SUBJECT AREA OF 38.03.02 “MANAGEMENT» ON THE EXAMPLE OF SFEDU

\begin{tabular}{|l|l|}
\hline \multicolumn{1}{|c|}{ Competencies } & $\begin{array}{l}\text { Number of } \\
\text { disciplines }\end{array}$ \\
\hline $\begin{array}{l}\text { the ability to use the basics of philosophical knowledge to } \\
\text { develop a worldview position (GCC-1) }\end{array}$ & 3 \\
\hline $\begin{array}{l}\text { the ability to analyze the main stages and patterns of the } \\
\text { historical development of society for the development of a } \\
\text { civic position (GCC-2) }\end{array}$ & 2 \\
\hline $\begin{array}{l}\text { the ability to use the basics of economic knowledge in } \\
\text { various fields (GCC-3) }\end{array}$ & 45 \\
\hline $\begin{array}{l}\text { ability to communicate verbally and in writing in Russian } \\
\text { and foreign languages for solving problems of interpersonal } \\
\text { and intercultural interaction (GCC-4) }\end{array}$ & 4 \\
\hline $\begin{array}{l}\text { ability to a teamwork tolerantly perceiving social, ethnic, } \\
\text { religious and cultural differences (GCC -5) }\end{array}$ & 35 \\
\hline capacity for self-organization and self-education (GCC -6) & 46 \\
\hline
\end{tabular}

\begin{tabular}{|l|l|}
\hline $\begin{array}{l}\text { the ability to use methods and techniques of physical } \\
\text { education to ensure full social and professional activities } \\
\text { (GCC-7) }\end{array}$ & \\
\hline $\begin{array}{l}\text { ability to use first aid techniques, methods of protection } \\
\text { in emergency situations (GCC-8) }\end{array}$ & 1 \\
\hline $\begin{array}{l}\text { possession of skills in the search, analysis and use of } \\
\text { regulatory and legal documents in professional activities }\end{array}$ & 16 \\
(GPC-1) & \\
\hline $\begin{array}{l}\text { the ability to find organizational and managerial decisions } \\
\text { and the willingness to bear responsibility for them from the } \\
\text { social significance prospective of the decisions made (GPC }\end{array}$ & 21 \\
-2) & \\
\hline $\begin{array}{l}\text { the ability to design organizational structures, participate in } \\
\text { the development of human resources management } \\
\text { strategies of organizations, plan and carry out activities, } \\
\text { distribute and delegate authority, taking into account } \\
\text { personal responsibility for ongoing activities (GPC-3) }\end{array}$ & 17 \\
\hline $\begin{array}{l}\text { the ability to conduct business communication and public } \\
\text { speaking, conduct negotiations, meetings, business } \\
\text { correspondence and to realize communications via } \\
\text { electronic facilities (GPC-4) }\end{array}$ & 21 \\
\hline $\begin{array}{l}\text { Skills in preparing financial statements, taking into account } \\
\text { the effects of various methods and methods of financial } \\
\text { accounting on the financial results of the organization based } \\
\text { on the use of modern methods of processing business } \\
\text { information and corporate information systems (GPC -5) }\end{array}$ & 24 \\
\hline $\begin{array}{l}\text { knowledge of decision-making methods in managing the } \\
\text { operational (production) activities of organizations (GPC - } \\
6 \text { ) }\end{array}$ & 12 \\
\hline $\begin{array}{l}\text { the ability to solve the standard tasks of professional } \\
\text { activity based on information and bibliographic culture } \\
\text { using information and tlecommunication technologies and } \\
\text { taking into account the basic requirements of information } \\
\text { security (GPC -7). }\end{array}$ \\
\hline
\end{tabular}

A change in the educational paradigm, a transition to a twolevel system of training and a significant redistribution of the teaching load and a reduction in classroom hours in favor of independent work of students led to a transition from a translational (linear) model of training - classroom lectures to forms of an interactional model - case study method, project teaching method, modeling and simulation. [4]

There are a number of methods that contribute to the development of students' soft skills. Among them, there are the case study method, the project teaching method and the interactive techniques that imitate the real professional activity. Let us consider them in more detail.

The case study method is one of the most effective training methods, the essence of which is to solve the case, the substantial part of which, in turn, is a real economic or business problem. Students get acquainted with such a problem and find an independent solution during a collective discussion in minigroups. In addition to professional competencies, when solving a specific case, the participants of the educational process develop such "soft skills" as self-management, managerial skills, communication skills, teamwork, emotional intelligence, problem solving skills.

The method of project teaching involves the selection and use by students of a certain set of educational and cognitive techniques that allow them to independently solve a particular educational problem and get a tangible result. The project teaching method involves the use of a wide range of techniques and methods and allows you to develop such skills related to 
soft skills as communication and teamwork skills, problem solving skills, skills of informed leadership.

One of the effective learning methods that are widely used to form both professional competencies of students and soft skills are interactive technologies that imitate real professional activity. A business role-playing game and management decision simulation allow students to master professional competencies in the context of imitating of future professional activities. The use of this training technology allows you to actualize professional knowledge, as well as to increase the level of cognitive motivation in mastering the skills of professional communication, to improve the level of critical thinking [3].

\section{RESULTS OF RESEARCH}

Currently, employers are beginning to pay more attention not to the specific education received by the graduate, but to the skills and competencies that he possesses. For example, the Atlas of new professions, developed by the Agency for Strategic Initiatives, is built taking into account related and cross-professional skills that allow a person not only to be highly effective in professional activities, but also, if necessary, to change his sphere of activity (even changing the industry), while maintaining his relevance.

Among the over-professional skills highlighted by experts, the following are noted: environmental thinking; project management; systemic thinking; work with people; work in an uncertain environment; programming, robotics, artificial intelligence; artistic creativity skills; multilingualism and multiculturalism; intersectoral communication; customer focus; lean manufacturing [5]. We can see that at most a greater number of the listed cross-professional competencies either repeat soft skills, or can only be obtained if they are sufficiently developed.

The development of soft skills and professional competencies should be inseparable. So in (Table 2) the basic soft skills and methods, due to which they can be developed are presented [6].

TABLE II. SOFT SKILLS AND METHODS OF THEIR DEVELOPMENT AT THE UNIVERSITY

\begin{tabular}{|c|c|}
\hline Name & Methods \\
\hline Sociabilty & $\begin{array}{l}\text { - } \quad \text { project teamwork on real cases; } \\
\text { - participation in pitch sessions and student } \\
\text { events; } \\
\text { - participation in conferences, forums and } \\
\text { outdoor events }\end{array}$ \\
\hline Teamwork & $\begin{array}{l}\text { - } \quad \text { any kind of teamwork } \\
\text { - } \quad \text { business role-playing games; } \\
\text { - } \quad \text { simulation games; }\end{array}$ \\
\hline Leadership & $\begin{array}{l}\text { - } \quad \text { project teamwork on real cases; } \\
\text { - } \quad \text { any kind of teamwork; } \\
\text { - } \quad \text { business role-playing games; }\end{array}$ \\
\hline Creativity & $\begin{array}{l}\text { - } \quad \text { case-study; } \\
\text { - } \quad \text { business role-playing games; } \\
\text { - } \quad \text { simulation games; }\end{array}$ \\
\hline Time-management & $\begin{array}{ll}\text { - } & \text { project teamwork; } \\
\text { - } & \text { Internet-baesd teaching } \\
\end{array}$ \\
\hline
\end{tabular}

Also, among other things, universities and third-party organizations offer students a wide range of programs and additional activities, participating in which during training they can develop both soft skills and professional competencies.

For example, the Russian Federation is currently actively involved in WorldSkills programme, which promotes vocational, technical and service-oriented education and training. Among the main projects, the following can be distinguished: holding championships for young specialists, establishment of specialized centers of competencies, establishment of centers of advanced professional training.

Also in our country, the project "Professional internships 2.0 " is being implemented these days. The project includes, among other things, the student work contest "Professional internships", the form of participation here is to write a scientific paper to solve a real business problem. In case of successful pass of the offered solution, a student may get an invitation to an internship or further work at a Company. Besides there functions an all-Russian base (aggregator) of internships, which allows students to look for places to undergo practical training directly in their specialty and get additional job opportunities immediately after graduation.

At the same time, universities also have experience in creating their own laboratories for the development of soft skills among students. For example, "Soft Skills Laboratory" operates at Southern Federal University, it was created to help young professionals (students and university graduates at the start of their careers) to become more competitive in the modern labor market by developing their soft skills that are in demand among employers [7].

The work of the Laboratory is built so that to take into account the following stages: assessment of the level of development of soft skills by means of testing; elaboration of an individual development plan taking into account the test data; drawing up a training program based on a matrix of courses, including 19 courses for 11 soft skills (Fig. 2).

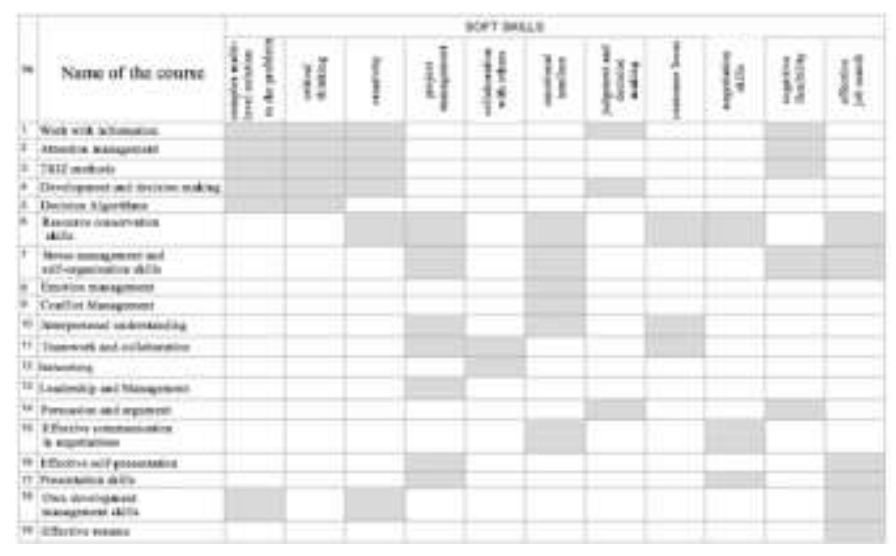

Fig. 2. Matrix of courses for the development of Flexible skills within the framework of the "Soft Skills Competency Lab"

At the same time, the studentы can develop their soft skills not only within the framework of these courses, but also by 
taking part in the activities of "Tochka kipeniya" created at the university. Participation in events is also reflected in students' accounts of Leader-ID platform, which allows to maintain a digital portfolio for the development of soft skills and professional competencies.

\section{CONCLUSIONS}

Thus, it can be stated that every year, especially in connection with changes in technology and the economy, the role of soft skills both in the process of professional development and the success of employees and in life increases. According to recent studies, $93 \%$ of employers pay the most attention in the selection of personnel precisely to the presence of soft skills and competencies.

This is also confirmed by the fact that according to the World Economic Forum, by 2020 the most demanded competencies will have been: the ability to solve complex problems, critical thinking, creativity, people management, coordination and interaction skills, emotional intelligence, judgment and speed of decision-making, client-focusedness, negotiation skills, cognitive flexibility. [8]

At the same time, it is proved that the higher a person ascends the career ladder (for example, according to experts in the professional field, an employee success depends on soft skills by $85 \%$ ), the more important role the soft skills of a person begin to play [9]. That is why the largest number of trainings and blocks in continuing education is devoted to the development of soft skills.

Thus, we can conclude that soft skills can be developed in all areas of educational activity, since full-time study allows you to simultaneously work on the development of both professional competencies and soft skills through a combination of full-time presence and distance education technologies, as well as through the constant necessity to establish contacts with fellow students and teachers, to defend projects and interact in groups [6].

\section{REFERENCES}

[1] OECD (2017), Education at a Glance 2017: OECD Indicators, OECD Publishing, Paris. Availiable at: http://dx.doi.org/10.1787/eag-2017-en (Acsessed: 01.10.2019).

[2] Bika N. How to assess soft skills in an interview // Sait Workable. Availiable at: https://resources.workable.com/tutorial/soft-skillsinterview-questions (Acsessed: 01.10.2019).

[3] Agapova G.Kh., Kulaeva G.M. Teaching students of the technical college of professional speech based on the use of business game technology. Bulletin of the Orenburg State Pedagogical University. Electronic scientific journal. 2016. No 2. PP. 232-238 (in Russian).

[4] Kashkin V. B Telementation vs. Interaction: Which Model Suits Human Communication Best? Journal of Siberian Federal University. Humanities \& Social Sciences. 2012. No 12 (5). PP. 1733-1742. (in Russian).

[5] Atlas novyh professij [Atlas of new professions]. Availiable at: http://atlas100.ru (Acsessed: 02.10.2019) (in Russian).

[6] Raitskaya L.K., Tikhonova E.V. Soft skills in the presentation of teachers and students of Russian universities in the context of world experience. Vestnik RUDN. Seriya: Psihologiya i pedagogika [Vestnik RUDN. Series: Psychology and Pedagogy]. 2018. V. 15. No 3. PP. 350363 (in Russian).

[7] Soft Skills Competency Lab. Availiable at: http://softskills.sfedu.ru (Acsessed: 03.10.2019) (in Russian).

[8] 10 competencies to be claimed in 2020 // Sait HR-Portal. Availiable at: https://hr-portal.ru/article/10-kompetenciy-kotorye-budut-vostrebovanyv-2020-godu (Acsessed: 03.10.2019) (in Russian).

[9] Ivonina A.I., Chulanova O.L., Davletshina Yu.M. Modern areas of theoretical and methodological developments in the field of management: the role of soft-skills and hard skills in the professional and career development of employees // Internet journal "SCIENCE". 2017. V. 9, No 1. Availiable at: http://naukovedenie.ru/PDF/90EVN117.pdf (Acsessed: 03.10.2019) (in Russian). 